\title{
Gambaran Ultrasonografi Ginjal pada Penderita Gagal Ginjal Kronik di Bagian Radiologi FK Unsrat/SMF Radiologi RSUP Prof. Dr. R. D. Kandou Manado Periode 1 April - 30 September 2015
}

\author{
${ }^{1}$ Nafira S. M. Gani \\ ${ }^{2}$ Ramli Hadji Ali \\ ${ }^{2}$ Bobby Paat
}

\author{
${ }^{1}$ Program Studi Pendidikan Dokter Fakultas Kedokteran Universitas Sam Ratulangi Manado \\ ${ }^{2}$ Bagian Radiologi Fakultas Kedokteran Universitas Sam Ratulangi Manado \\ ${ }^{3}$ KSM Bagian Radiologi RSUP Prof. Dr. R. D. Kandou Manado \\ Email: nafiragani12146@gmail.com
}

\begin{abstract}
Chronic renal failure (CRF) is a chronic disorder of renal function which develops progressively and irreversibly. Ultrasonography (USG) is currently used as the first examination in CRF patients to obtain some information about the parenchym, collecting system, and renal vasculature. Abdominal USG in CRF patients is usually characterized by a more hyperchoic cortex which is almost the same as the renal sinus. This study was aimed to obtain the profile of renal USG of CRF patients at the Radiology Departement of Medical Faculty Sam Ratulangi University/Prof Dr. R. D. Kandou Hospital Manado during April 1 to September 30, 2015. This was a retrospective descriptive study using medical record data at the Radiology Departement. Samples were all request paper of patients diagnosed as CRF with USG performed on them. The results showed 64 CRF cases with renal USG. Patients with CRF were most males (78.5\%) and age group 56 - 65 years (29.7\%). Most patients with CRF had bilateral renal disorder (98.5\%). Conclusion: Most patients with chronic renal failure were males, age group of 56-65 years old, and had affected kidneys bilaterally.
\end{abstract}

Keywords: ultrasonography, chronic renal failure (CRF)

\begin{abstract}
Abstrak: Gagal ginjal kronik (GGK) adalah gangguan fungsi ginjal yang menahun, bersifat progresif dan ireversibel. Ultrasonografi (USG) saat ini digunakan sebagai pemeriksaan pertama secara rutin pada keadaan gagal ginjal untuk memperoleh informasi tentang parenkim, sistem kolekting, dan pembuluh darah ginjal. Ultrasonografi abdomen pada pasien GGK biasanya ditandai dengan kortek yang lebih hiperekoik hingga hampir sama dengan sinus renalis. Penelitian ini bertujuan untuk mendapatkan gambaran USG ginjal pada penderita GGK di Bagian Radiologi FK Unsrat/SMF Radiologi RSUP Prof. Dr. R. D. Kandou Manado. Jenis penelitian ialah deskriptif retrospektif dengan memanfaatkan data rekam medik di Bagian Radiologi. Sampel penelitian ialah semua lembaran permintaan penderita yang sudah didiagnosis GGK dengan pemeriksaan USG ginjal di Bagian Radiologi RSUP Prof. Dr. R. D. Kandou Manado periode 1 April-30 September 2015. Hasil penelitian mendapatkan 64 kasus GGK pada periode tersebut; lebih banyak pada laki-laki (78,5\%) dan kelompok usia 56-65 tahun $(29,7 \%)$. Penderita GGK terbanyak ditemukan bilateral $(98,5 \%)$. Simpulan: Penderita GGK terutama ditemukan pada jenius kelamin laki-laki, kelompok usia 56-65 tahun, dan terjadi bilateral.
\end{abstract}

Kata kunci: ultrasonografi Ginjal, gagal ginjal kronik (GGK)

Gagal ginjal kronik (GGK) adalah gangguan fungsi ginjal menahun bersifat progresif dan ireversibel. ${ }^{1}$ Penyebab GGK yang sering ditemukan ialah infeksi atau 
peradangan, penyakit vaskular terutama hipertensi, gangguan jaringan penyambung, gangguan kongenital herediter, penyakit metabolik, nefropati toksik, dan nefropati obstruktif. ${ }^{2}$ Gagal ginjal kronik merupakan masalah kesehatan masyarakat di seluruh dunia dan kini diakui sebagai suatu kondisi umum yang dikaitkan dengan peningkatan risiko penyakit dan GGK. Berdasarkan etimasi World Health Organization (WHO), secara global lebih dari 500 juta orang mengalami GGK. Diperkirakan bahwa sedikitnya $6 \%$ pada kumpulan populasi dewasa di Amerika Serikat telah menderita GGK dengan LFG >60 ml/mnt $1,73 \mathrm{~m}^{2}$ (derajat 1 dan 2). Selain itu, $4,5 \%$ dari populasi Amerika Serikat telah berada pada derajat 3 dan 4. Data pada tahun 1995-1999, menyatakan bahwa di Amerika Serikat insiden penyakit ginjal kronik diperkirakan meningkat $8 \%$ setiap tahun. ${ }^{3}$ Di Malaysia dengan populasi 18 juta, diperkirakan 1800 kasus baru gagal ginjal per tahun. Di negara-negara berkembang lainnya, insiden ini diperkirakan sekitar 4060 juta per tahun. ${ }^{4}$ Di Indonesia, dari data yang didapatkan berdasarkan serum kreatinin yang abnormal, diperkirakan pasien dengan GGK sekitar 2000 per juta penduduk. Sulawesi Utara menempati urutan ke 4 tertinggi dari 33 provinsi dengan prevalensi $0,4 \%$ pada tahun 2013 (Riskesdas 2013). Di Sulawesi Utara sendiri penyakit GGK yang menjalani terapi hemodialisis 130 pasien dalam periode waktu 1 bulan; setiap pasien memiliki jadual pemeriksan yang telah ditentukan untuk terapi. ${ }^{5}$

Pemeriksaan penunjang radiologis yang umumnya dilakukan pada pasien GGK ialah pemeriksaan ultrasonografi (USG). Ultrasonografi saat ini digunakan sebagai pemeriksaan pertama secara rutin pada keadaan gagal ginjal untuk memperoleh informasi tentang parenkim, sistem collecting dan pembuluh darah ginjal. ${ }^{6}$

Pemeriksaan USG pada ginjal untuk mengetahui adanya pembesaran ginjal, kristal, batu ginjal, dan mengkaji aliran urin dalam ginjal. ${ }^{7}$ Ultrasonografi abdomen pada pasien GGK biasanya ditandai dengan korteks yang lebih hiperekoik hingga hampir sama dengan sinus renalis. Selain itu dapat pula ditemukan ukuran ginjal yang mengecil dan batas korteks medula yang tidak jelas. Pada pemeriksaan USG gambaran hiperekoik pada parenkim ginjal kanan dapat menimbulkan kecurigaan adanya radang pada ginjal kanan. Normalnya, parenkim ginjal pada bagian korteks memiliki sonodensitas yang lebih rendah dari pada hepar, sehingga bersifat hiperekoik. Penelitian ini bertujuan untuk mengetahui gambaran USG ginjal pada penderita GGK di Bagian Radiologi FK Unsrat/SMF Radiologi RSUP Prof. Dr. R. D. Kandou Manado periode 1 April-30 September 2015.

\section{METODE PENELITIAN}

Jenis penelitian ini ialah deskriptif retrospektif, yang dilaksanakan di Bagian Radiologi FK Unsrat/SMF Radiologi RSUP Prof. Dr. R. D. Kandou Manado. Populasi penelitian ialah seluruh lembaran permintaan pemeriksaan USG ginjal sedangkan sampel penelitian ialah seluruh lembaran permintaan pemeriksaan pasien dengan diagnosis radiologis GGK pada USG ginjal. Variabel penelitian yaitu: usia, jenis kelamin, dan lokasi gagal ginjal.

Data diperoleh secara retrospektif berdasarkan lembaran permintaan pemeriksaan USG ginjal penderita dengan diagnosis klinis GGK dalam kurun waktu 6 bulan. Data yang terkumpul kemudian diolah dan disajikan dalam bentuk tabel.

\section{HASIL PENELITIAN}

Penelitian ini dilaksanakan di Bagian Radiologi FK Unsrat/SMF Radiologi RSUP Prof. Dr. R. D. Kandou Manado.

Distribusi penderita GGK terbanyak pada usia 55-65 tahun $(29,7 \%)$ (Tabel 1). Distribusi penderita GGK berdasarkan jenis kelamin memperlihatkan bahwa yang terbanyak ialah jenis kelamin laki-laki $(78,5 \%)$ (Tabel 2). Distribusi penderita GGK berdasarkan lokasi gangguan ginjal memperlihatkan bahwa sebagian besar penderita dengan gangguan ginjal bilateral (Tabel 3). 
Tabel 1. Distribusi penderita gagal ginjal kronik berdasarkan golongan usia

\begin{tabular}{ccc}
\hline $\begin{array}{c}\text { Usia } \\
\text { (tahun) }\end{array}$ & Jumlah & $\begin{array}{c}\text { Persentase } \\
(\boldsymbol{\%})\end{array}$ \\
\hline$<25$ & 3 & 4,7 \\
$26-35$ & 3 & 4,7 \\
$36-45$ & 5 & 7,7 \\
$46-55$ & 17 & 26,6 \\
$56-65$ & 19 & 29,7 \\
$>65$ & 17 & 26,6 \\
Total & 64 & 100 \\
\hline
\end{tabular}

Tabel 2. Distribusi sampel berdasarkan jenis kelamin

\begin{tabular}{ccc}
\hline $\begin{array}{c}\text { Jenis } \\
\text { kelamin }\end{array}$ & Jumlah & $\begin{array}{c}\text { Persentase } \\
(\boldsymbol{\%})\end{array}$ \\
\hline Laki-laki & 50 & 78,5 \\
Perempuan & 14 & 21,5 \\
Total & 64 & 100 \\
\hline
\end{tabular}

Tabel 3. Distribusi sampel berdasarkan lokasi gangguan ginjal

\begin{tabular}{ccc}
\hline Lokasi & Jumlah & $\begin{array}{c}\text { Persentase } \\
(\boldsymbol{\%})\end{array}$ \\
\hline Bilateral & 63 & 98,5 \\
Sinistra & 1 & 1,5 \\
Dextra & 0 & 0 \\
Total & 64 & 100 \\
\hline
\end{tabular}

\section{BAHASAN}

Pada penelitian ini, penderita dengan diagnosis GGK berdasarkan hasil USG berjumlah 64 orang dan paling banyak terjadi pada golongan usia 56-65 tahun yaitu sebanyak 19 penderita $(29,7 \%)$ (Tabel 1). Penelitian yang dilakukan oleh Tjekyan ${ }^{8}$ di RSUP Dr. Mohammad Hoesin Palembang mendapatkan kasus GGK terbanyak pada usia 50-59 tahun (27,3\%). Bertambahnya usia akan memengaruhi anatomi, fisiologi, dan sitologi pada ginjal. Setelah usia 30 tahun, ginjal akan mengalami atrofi dan ketebalan kortek ginjal akan berkurang sekitar $20 \%$ setiap dekade. Perubahan lain yang akan terjadi seiring dengan bertambahnya usia berupa penebalan membran basal glomerulus, ekspansi mesangium ekstrasel sehingga menyebabkan glumerulosklerosis.

Hasil penelitian memperlihatkan bahwa penderita GGK terbanyak pada laki-laki yaitu 50 orang $(78,5 \%)$. Hasil penelitian ini sejalan dengan yang dilakukan oleh Sari et al. ${ }^{9}$ di RSU Haji Medan yang mendapatkan distribusi proporsi laki-laki $(50,6 \%)$ lebih tinggi dibandingkan dengan perempuan $(49,4 \%)^{9}$

Pada Tabel 3 terlihat bahwa lokasi GGK banyak terdapat bilateral yaitu 63 penderita $(98,5 \%)$, kemudian pada ginjal sinistra 1 penderita $(1,5 \%)$.

\section{SIMPULAN}

Berdasarkan hasil penelitian yang dilakukan di Bagian Radiologi FK Unsrat/ SMF radiologi RSUP Prof. Dr. R. D. Kandou Manado periode 1 April-30 September 2015 dengan menggunakan data gambaran ultrasonografi ginjal maka dapat disimpulkan bahwa kasus GGK lebih banyak terjadi pada laki-laki, golongan usia 56-65 tahun, dengan lokasi gangguan ginjal bilateral.

\section{SARAN}

Kelengkapan data pada lembaran permintaan pada pemeriksaan ultrasonografi harus ditingkatkan, karena hal tersebut sangat penting bagi kebutuhan rumah sakit termasuk untuk menunjang penelitian-penelitian selanjutnya.

Masyarakat sebaiknya lebih memperhatikan dan merubah gaya hidup untuk mencegah terjadinya gagal ginjal kronik.

\section{DAFTAR PUSTAKA}

1. Sudoyo AW, Setiyohadi B, Alwi I, Simadibrata M, Setiati S. Ilmu Penyakit Dalam Vol.1 (4th ed). Jakarta: FKUI, 2007; p. 570.

2. Wilson LM. Anatomi dan fisiologi ginjal dan saluran kemih. In: Price SA, Wilson LM, editors. Patofisiologi Volume 2 (6th ed). Jakarta: EGC, 2003; p. 865, 867-868, 912, 917-918, 965.

3. Sudoyo AW, Setiyohadi B, Alwi I, Simadibrata M, Setiati S. In Ilmu Penyakit Dalam Jilid II (5th ed). Jakarta: Penerbit Interna Publishing, 2009; p. 1035-40.

4. Suwitra K. Penyakit ginjal kronik. In: Sudoyo AW, Setiyohadi B, Alwi I, Simadibrata M, Setiati S, editors. Buku Ajar Ilmu 
Penyakit Dalam Jilid I (4th ed). Jakarta: Bagian Ilmu Penyakit Dalam FKUI, 2007; p. 570-3.

5. Riskesdas. 2013. Laporan Nasional Riskesdas 2013. Available from: http: //litbang.depkes.co.id.

6. Boediwarsono. Gagal Ginjal Akut. Segi Praktis Pengobatan Penyakit Dalam. Surabaya: Penerbit PT Bina Indra Karya, 1985.

7. Kamaludin A. Gagal Ginjal Kronik. Jakarta: Bagian Ilmu Penyakit Dalam UPH,
2010.

8. Tjekyan R. Prevalensi dan faktor risiko penyakit ginjal kronik di RSUP Dr. Mohammad Hoesin Palembang tahun 2012. MKS. 2014;46(4):277.

9. Sari I, Jemadi, Hiswani. Karakteristik penderita gagal ginjal kronik yang rawat inap di Rumah Sakit Umum Haji Medan tahun 2011-2013. Gizi, Kesehatan Reproduksi dan Epidemiologi. 2014;1(3). 